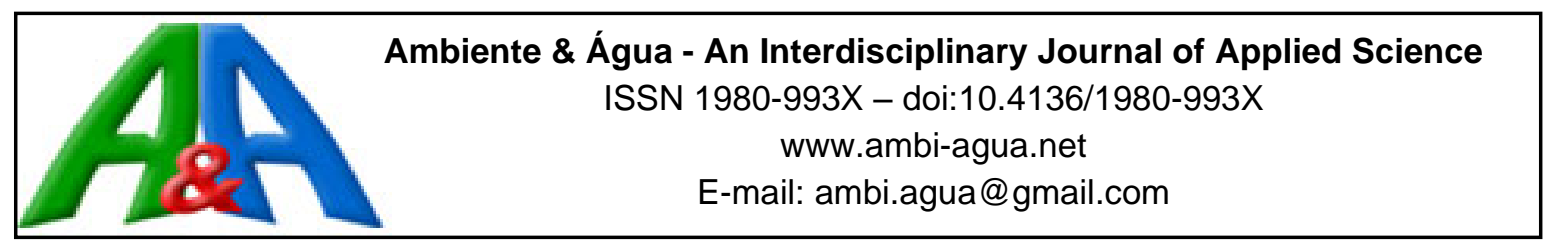

\title{
Biodegradation of dairy wastes using crude enzymatic extract of Yarrowia lipolytica ATCC 9773
}

\author{
ARTICLES doi:10.4136/ambi-agua.2448
}

Received: 17 Jul. 2019; Accepted: 10 Dec. 2019

\section{Arnulfo Tarón Dunoyer ${ }^{*}$ (D); Rafael Emilio González Cuello1 ${ }^{1}$; Rosangela Perez Salinas ${ }^{2}$ ic}

\footnotetext{
${ }^{1}$ Faculty of Engineering. University of Cartagena, Campus Piedra de Bolivar. Consulate Avenue, 30th Street, $\mathrm{n}^{\circ}$ 48-152, Cartagena, Colombia. E-mail: rgonzalezc1@unicartagena.edu.co

${ }^{2}$ Faculty of Health Sciences. University of Santander, Center neighborhood, 6th Race, $\mathrm{n}^{\circ} 14-27$, Valledupar, Colombia. E-mail: ros.perez@mail.udes.edu.co

*Corresponding author. E-mail: atarond@unicartagena.edu.co
}

\begin{abstract}
Effluents generated by the food industry have become a serious environmental concern. Bioremediation is a biological process developed as an alternative for the treatment of contaminated areas. In current research, the biodegradation of fat, Biochemical Oxygen Demand (BOD 5 ), Chemical Oxygen Demand (COD) and total solids were evaluated in dairy waste employing enzymatic extract of Yarrowia lipolytica ATCC 9773 as biological agents. All the variables were determined following the specifications of the Standard Methods of the American Water Works Association. Enzymatic extract of $Y$. lipolytica at different concentrations $(8,12$ and $16.0 \%)$ was used in a fermentative medium at two pHs (5.0 and 6.5) for $32 \mathrm{~h}$. The highest percentages (\%) of fat (82.88), BOD (43.32), COD (44.3) and total solids (13.58) removal were obtained using an inoculum concentration of $16 \%$ at $\mathrm{pH} 5.0$ for $32 \mathrm{~h}$ of fermentation. These results may have industrial relevance for the reduction of contamination of industrial effluents with high levels of fat and other contaminants.
\end{abstract}

Keywords: biological treatment, fatty effluents, removal, $Y$ lipolytica.

\section{Biodegradação de um residuo leiteiro usando Yarrowia lipolytica ATCC 9773}

\section{RESUMO}

Os efluentes gerados pela indústria de alimentos tornaram-se uma séria preocupação ambiental. A biorremediação é um processo biológico desenvolvido como alternativa para o tratamento de áreas contaminadas. Na pesquisa atual, a biodegradação de gordura, a demanda bioquímica de oxigênio ( $\mathrm{DBO}_{5}$ ), a demanda química de oxigênio (DQO) e os sólidos totais foram avaliados como rejeitos lácteos empregando extrato enzimático de Yarrowia lipolytica ATCC 9773 como agentes biológicos. Todas as variáveis foram determinadas seguindo as especificações dos Métodos Padrão da American Water Works Association. O extrato enzimático de Y. lipolytica em diferentes concentrações $(8,12$ e 16,0\%) foi utilizado em meio fermentativo a dois $\mathrm{pH}(5,0$ e 6,5$)$ durante $32 \mathrm{~h}$. As maiores porcentagens $(\%)$ de remoções de gordura $(82,88)$, DBO $(43,32)$, DQO $(44,3)$ e sólidos totais $(13,58)$ foram obtidas utilizando 
uma concentração de inóculo de 16\% a pH 5,0 durante 32 h de fermentação. Esses resultados podem ter relevância industrial para a redução da contaminação de efluentes industriais com altos níveis de gordura e outros contaminantes.

Palavras-chave: efluentes gordurosos, remoção, tratamento biológico, Y lipolytica.

\section{INTRODUCTION}

The food industry is a sector with a high incidence of environmental pollution. Different industries such as dairy, meat and vegetable oil refining produce large amounts of wastewater. The high oil content of these increase the spoilage of some ecosystems (Porwal et al., 2015).

Dairy wastes are pollutants that affect the environment when they are discarded without adequate treatment (Liu et al., 2015b). In the last decades, fatty effluents have been released to the environment without previous treatment (Kumari et al., 2017; Tarón-Dunoyer et al., 2017), which affects public health and environmental sustainability. Considering the aforementioned, the treatment of fatty effluents is an economic and hygienic requirement.

Many of these effluents require pretreatment in order to remove incompatible substances before they are discharged into sewer systems (Kumari et al., 2017; Pilusa et al., 2013). The main components present in wastewater are: oils, fats and long-chain fatty acids, which represent a great problem in the pretreatment due to the fact that they are contaminants of aquatic ecosystems (Becerra-Gutiérrez et al., 2015; Fachin et al., 2013; Abass et al., 2011)

Currently, there has been an emphasis on finding new biotechnological alternatives for the treatment of wastewater that also minimize the adverse effects previously mentioned. Biological treatment is one alternative used to decontaminate wastewater, where lipolytic properties of living organisms are employed to eliminate high-fat waste from the aquatic ecosystem (González et al., 2012; Kushwaha et al., 2011). Various microorganisms such as filamentous fungi, bacteria and yeast are well known as lipolytic microorganisms. Within this group of microorganisms, the yeast Yarrowia lipolytica is highlighted due to its extracellular and intracellular activity (Darvishi et al., 2017). Its lipase production depends on the medium composition and environmental conditions (Deive et al., 2010).

Yarrowia lipolytica is an adequate biological agent for biodegradation of substrates with a high fat content (Lopes et al., 2018). Y. lipolytica has been approved as GRAS (Generally Recognized As Safe) in several industrial processes. Yarrowia sp. have been isolated from lipidrich foods such as cheese and olive oil as well as from wastewater (Aloulou et al., 2007). The preference of $Y$. lipolytica for these substrates has been attributed to the efficient production and secretion of proteolytic enzymes (Fickers et al., 2005; Liu et al., 2015a; Brigida et al., 2014). In this sense, there are no references in the literature regarding the use of crude enzymatic extract for the biodegradation of dairy waste. Hence, this research focused on the utilization and evaluation of the biodegradation capacity of the crude enzymatic extract of Yarrowia lipolytica ATCC 9773 in dairy waste.

\section{MATERIALS AND METHODS}

\subsection{Biological material}

Yarrowia lipolytica strain (ATCC 9773) was purchased from Medimark (C) Europe, 38033 Grenoble Cedex 2. France.

\subsection{Industrial dairy waste}

The dairy waste sample was obtained from a dairy industry located in Valledupar (Colombia). The sample was collected in an $8 \mathrm{~L}$ plastic container. The container used for sample 
collection was pre-treated by washing with alcohol and later rinsed four times with distilled water. The sample was stored at a temperature below $4^{\circ} \mathrm{C}$ to avoid any physico-chemical changes in the effluent. Finally, the sample volume was divided in order for the $\mathrm{pH}$ values to be adjusted to 5.0 and 6.5 by employing $\mathrm{HCl}$ solution $0.5 \mathrm{~N}$.

\subsection{Activation and conservation of Yarrowia lipolytica ATCC 9773}

The strain was inoculated at $25^{\circ} \mathrm{C}$ for three days in petri dishes containing PDA agar (Figure 1a) and olive oil as a lipid source. A microscopic morphology (Figure 1b) was then carried out employing lactophenol blue as colorant. Lastly, $0.5 \mathrm{~mL}$ of the inoculum was adjusted by turbidimetry at MacFarlan scale (3) and stored at $4^{\circ} \mathrm{C}$ until use.

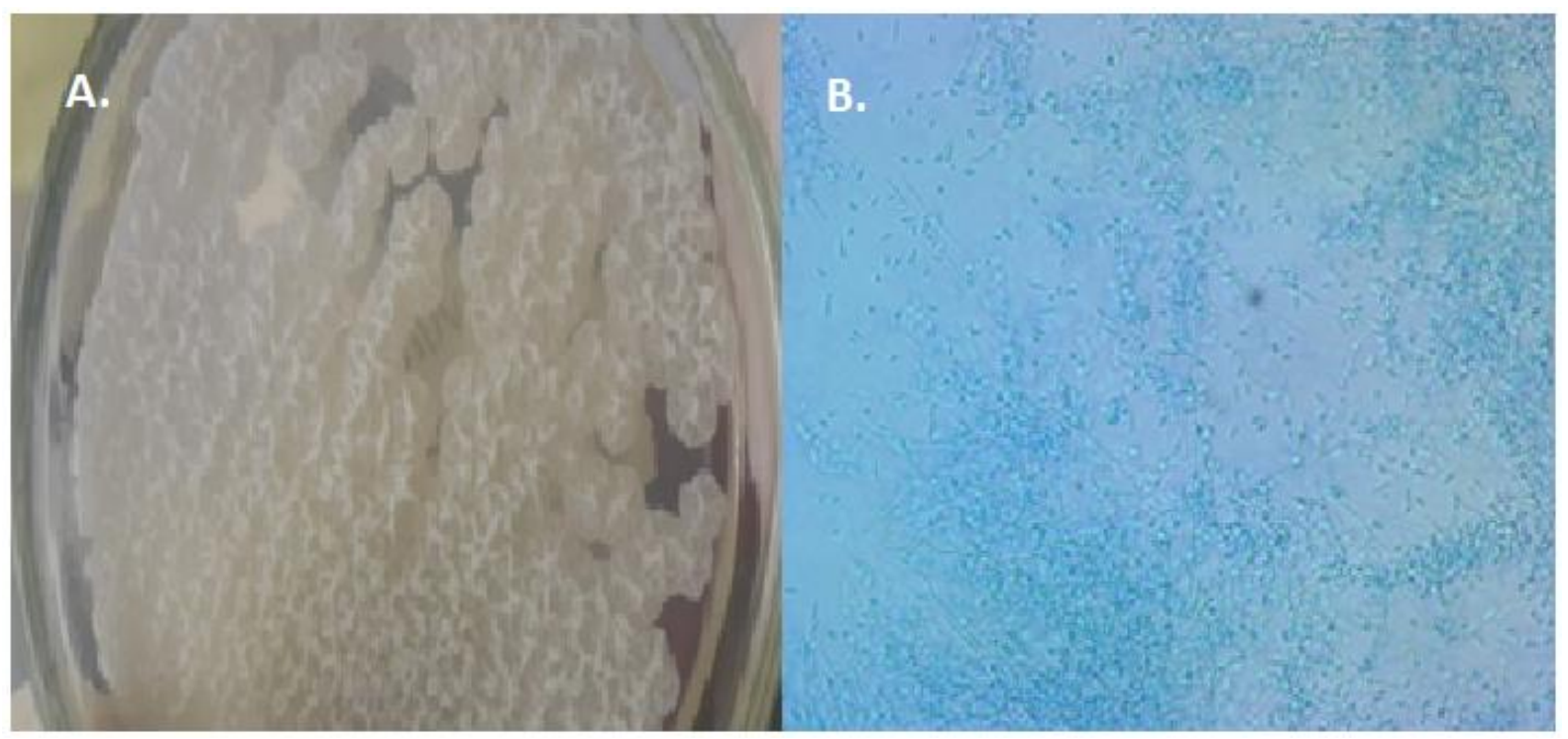

Figure 1. Morphology of Yarrowia lipolytica ATCC 9773: A) Macroscopic., B) Microscopic morphology.

\subsection{Preparation of the inoculum and obtaining the crude enzymatic extract (CEE)}

The inoculum was obtained from a suspension of mature spores of $Y$. lipolytica cultivated for five days at $25^{\circ} \mathrm{C}$ in PDA agar supplemented with olive oil. The biomass obtained was suspended in a solution of $0.9 \%(\mathrm{w} / \mathrm{v})$ sodium chloride $(\mathrm{NaCl})$. Subsequently, $200 \mathrm{~mL}$ of culture medium containing salt water $(30 \% \mathrm{SW})$, sodium chloride $(5.0 \%)$, yeast extract $(0.5 \%)$, olive oil $(1.0 \%)$ and Triton X-100 $(0.1 \%)$ were inoculated with a suspension of $Y$. lipolytica for an incubation time of 8 hours. The fungal biomass was then separated from the supernatant by centrifugation at $5000 \mathrm{rpm}$ for $10 \mathrm{~min}$. Finally, the supernatant [enzymatic extract (EE)], was filtered through cellulose acetate membranes $(0.22$ to $0.45 \mathrm{~mm})$ and the suspension cell viability was determined by spectrophotometry (Spectronic 20D) at $600 \mathrm{~nm}$ (Wu et al., 2009).

\subsection{Physicochemical effluent characterization}

The physicochemical analyses were performed using the Standard Methods protocols established for raw water and wastewater. The fat and oil content was determined by the Soxhlet method according to the Standard Methods of the APHA et al. (2012). The hardness was measured by titration using EDTA solution as titrating agent, the results were expressed as mg of $\mathrm{CaCO}_{3} / \mathrm{L}$ (Method $2340 \mathrm{C}$ ). Biological oxygen demand (BOD) was estimated by preparing the required volume of dilution water with the addition of nutrients and incubating for a period of five days at $20^{\circ} \mathrm{C}$, while chemical oxygen demand (COD) was determined based on the rapid dichromate oxidation method (APHA et al., 2012). The phosphorus content was determined by acid digestion, using the ascorbic acid method expressed in $\mathrm{mg}$ of P/L. Protein content was 
determined by the Kjeldahl method. Hydrogen potential was determined potentiometrically using a digital potentiometer (Bench pH-Conductivity meter PC 510).

\subsection{Evaluation of biodegradation}

This test was performed during the effluent's discontinuous fermentation using different concentrations $(8 \%, 12 \%$ and $16 \%)$ of CEE of $Y$. lipolytica, considering the volume of the effluent's residual fat ( $\mathrm{pH} 5$ and 6.5 at $25^{\circ} \mathrm{C}$ ). Fat content was determined each 8 hours until reaching 32 hours of fermentation. It is noteworthy to mention that $\mathrm{BOD}_{5}$ and $\mathrm{COD}$ were calculated only for that time where the best fat removal was reached (inoculum concentration: $16 \%$, incubation time: $32 \mathrm{~h}$ and $\mathrm{pH}: 5.0)$.

\subsection{Statistical analysis}

The percentage of fat removal was used as the response variable. These data were analyzed by means of analysis of variance (ANOVA one way) in order to determine statistically significant differences $(P<0.05)$ between the samples. SPSS software (Version 17.0 for Windows) and the multiple comparison test of Tukey were used. All tests were completed in triplicate.

\section{RESULTS AND DISCUSSION}

\section{Growth of Y. lipolytica}

The growth curve of Y. lipolytica ATCC 9773 under experimental conditions is illustrated in Figure $2 \mathrm{a}$ y $2 \mathrm{~b}$. These conditions were chosen from previous analyses of the research group. The figures show that there were mainly three phases: (1) lag phase, which lasted from 0 to 8 $\mathrm{h}$, and the absorbance was $0.332(\mathrm{pH} 5)$ and 0.044 (pH 6.5); (2) logarithmic phase, which lasted from 8 to $36 \mathrm{~h}$, and the absorbance increased from 0.332 to $1.319(\mathrm{pH} \mathrm{5)}$ and 0.044 to 0.412 ( $\mathrm{pH}$ 6.5); and (3) death phase, the absorbance decreased after $42 \mathrm{~h}$. It is interesting to mention that no stationary phase was observed, since the fermentation process was stopped at $44 \mathrm{~h}$, which was before the appearance of the stationary phase.

This experimental result showed that $Y$. lipolytica was capable of using oil salts as the sole source of carbon, nitrogen and energy, and $Y$. lipolytica presented remarkable growth in oil and salt wastewater.
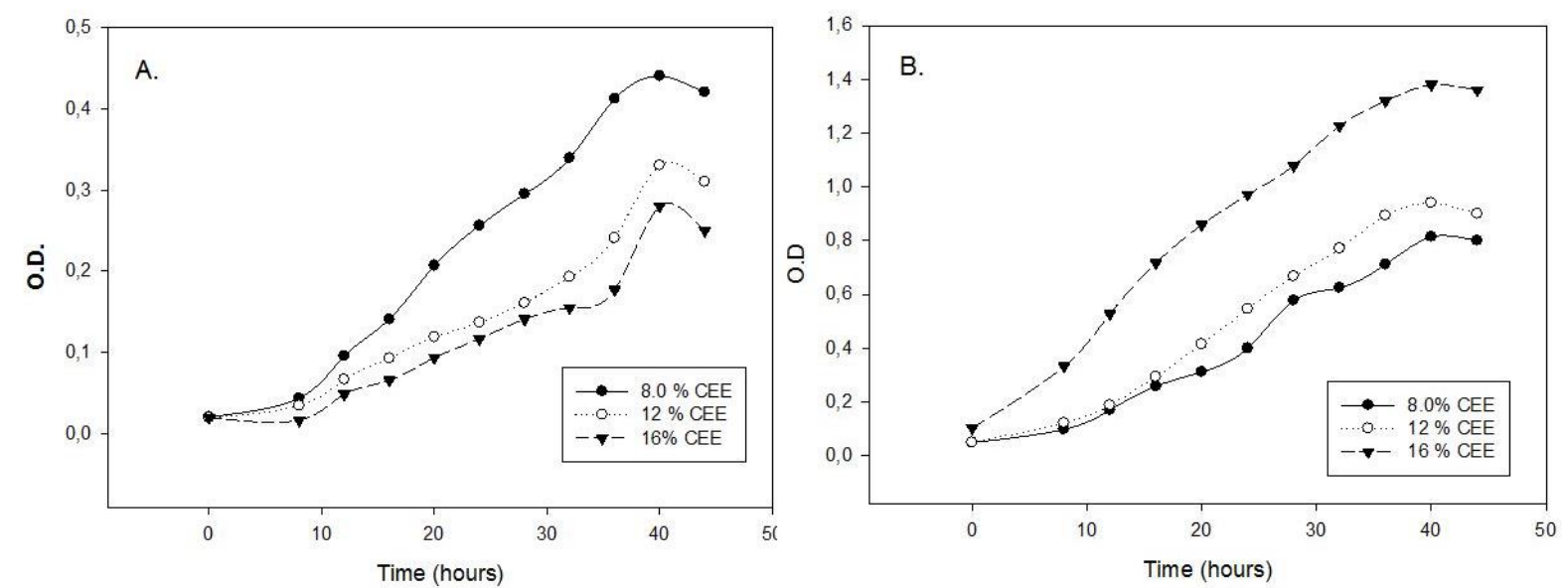

Figure 2. Growth curve of Yarrowia lipolytica ATCC 9773 at different pH values. A: pH 6.5; B: pH 5.0.

Table 1 shows the physical-chemical characterization of the effluent over the course of the experiment: 
Table 1. Physical-chemical characterization of the residual fat effluent before and after the biodegradation process using Y. lipolytica ATCC 9773 under different conditions.

\begin{tabular}{ccccc}
\hline Parameters & $C_{i}$ & $C_{f}(a)$ & $C_{f}(b)$ & Unit \\
\hline BOD $_{5}$ & $17299 \pm 14.8$ & $9805 \pm 21.2$ & $10680 \pm 75.5$ & $\mathrm{mg} \mathrm{de} 0_{2} / \mathrm{L}$ \\
COD & $53118 \pm 27.5$ & $29576 \pm 15.2$ & $32316 \pm 15.2$ & $\mathrm{mg} \mathrm{de} 0_{2} / \mathrm{L}$ \\
Fat & $3260 \pm 20.80$ & $558 \pm 5.290$ & $1083 \pm 8.540$ & $\mathrm{mg} / \mathrm{L}$ \\
pH & $8.080 \pm 0.00$ & $5.0 \pm 0.000$ & $6.5 \pm 0.000$ & $\mathrm{U} \mathrm{de} \mathrm{pH}$ \\
Total solids & $21308 \pm 14.4$ & $18415 \pm 29.7$ & $19676 \pm 92.9$ & $\mathrm{mg} / \mathrm{L}$ \\
Phosphorus & $<0.07$ & $<0.075$ & $<0.075$ & $\mathrm{mg} \mathrm{de} \mathrm{P/L}$ \\
Hardness & $486.6 \pm 5.77$ & $487.3 \pm 7.50$ & $503.3 \pm 5.7$ & $\mathrm{mg} \mathrm{CaCO}_{3} / \mathrm{L}$ \\
Protein & $2.26 \pm 0.057$ & $1.94 \pm 0.051$ & $1.81 \pm 0.028$ & $\%$ \\
\hline
\end{tabular}

$\mathrm{C}_{\mathrm{i}}$ : Initial conditions of the effluent. $\mathrm{C}_{\mathrm{f}}(\mathrm{a})$ : Final conditions; $\mathrm{pH} 5,0$ inoculum concentration of $16 \%, 32$ hours of fermentation.

$\mathrm{C}_{\mathrm{f}}(\mathrm{b})$ : Final conditions; $\mathrm{pH}$ 6,5 inoculum concentration of $8 \%, 32$ hours of fermentation.

According to the results of the $\mathrm{BOD}_{5}$ and $\mathrm{COD}$ analyses, the dairy residue can be considered highly biodegradable. Y lipolytica ATCC 9773 is able to reduce $\mathrm{BOD}_{5} 43.32 \%$ and COD $44.30 \%$. The best result in fat removal were obtained when a $\mathrm{pH}$ of 5 and an inoculum concentration of $16 \%$ were used. It seems that a $\mathrm{pH}$ increase in the effluent has effects on $Y$. lipolytica which influence its growth and therefore the lipases production.

One-way ANOVA of BOD 5 and COD values revealed significant differences $(\mathrm{p}<0.05)$ among the studied samples when the effluents' $\mathrm{pH}$ increased. Regarding to the inoculum concentration, also significant differences $(\mathrm{p}<0.05)$ were found at $\mathrm{pH} 5.0$ when inoculum increased; however, the same was not observed at $\mathrm{pH}$ 6.5. Similar results have been reported by other researchers (Wu et al., 2009; Wu and Wan, 2008) due to the fact that a high inoculum concentration can encourage microbial growth. Studies involving considerable reduction in COD and BOD in wastewater by using bacterial isolates have been published by Das and Santra (2010), Gaikwad et al. (2014). As with most other agro-industries, the dairy industry produces strong wastewaters characterized by COD and high BOD absorptions signifying their elevated organic content (Orhon et al., 1993). The drop in COD values may be due to the concentration of nutrients, which microbial cultures could use for growing. Current results are in accordance with the reduction in COD reported by Guillen-Jimenez et al. (2000), where maximum COD fall was found up to $65-70 \%$. Similar decrease in COD of the dairy wastewater $(99.9 \%)$ was noted by Cosa and Okoh (2014) with a consortium of two marine species.

When the $\mathrm{pH}$ is 5.0 and the inoculum concentration $16 \%$, the total solids removal reached values close to $13.58 \%$. These results are opposite those reported by Stefańsk et al. (2018) who reported similar removal values employing a $\mathrm{pH}$ of 6.5 and an inoculum concentration of $8 \%$. On the other hand, the hardness values are slightly higher than those initial values; this increase could be caused by the production of solid materials generated by the microbial growth.

Figure 3 shows the values of fat removal at different concentrations of inoculum $(8 \%, 12 \%$ and $16 \%$ ) in the effluent, adjusted at two $\mathrm{pH}$ values (5.0 and 6.5). To $\mathrm{pH} 5.0$ the highest fat removal values $(88.82 \%)$ were achieved using an inoculum concentration of $16 \%$ and $32 \mathrm{~h}$ fermentation time. No significant differences were found ( $>0.05)$ among different inoculum concentrations at the same fermentation times. It should be mentioned that significant differences $(\mathrm{p}<0.05)$ were found in fat biodegradation for all fermentation times.

The fermentative process at a $\mathrm{pH}$ of 6.5 using different inoculum concentrations is illustrated in Figure 3, where a removal percentage of $49.63 \%$ after 8 hours of fermentation may be observed. When the inoculum amount was increased, no significant differences $(\mathrm{P}>0.05)$ were appreciated in the fat removal percentage for different samples in the same 
fermentation time. After 8 hours of fermentation, the percentage of fat removal remained constant, although Y. lipolytica ATCC 9773 continues to present lipase activity, which results in a decreasing of fat percentage until 32 hours of fermentation time is reached.

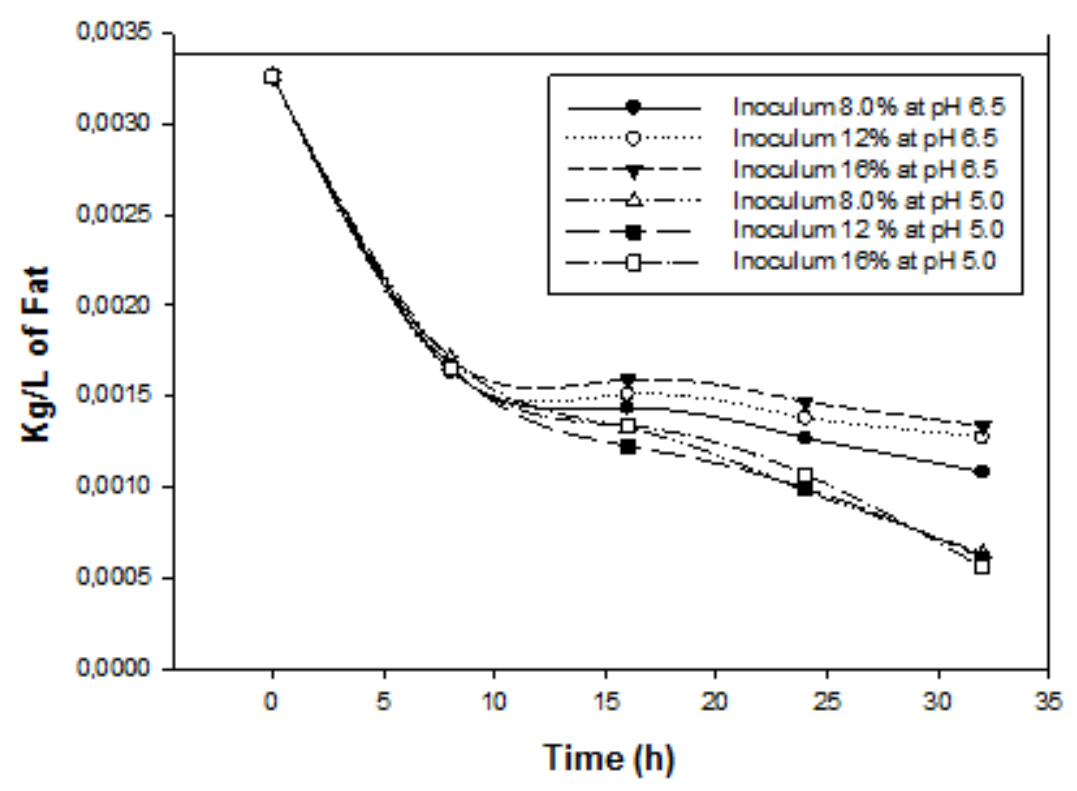

Figure 3. Fat removal from industrial effluent at different concentrations of CEE and a $\mathrm{pH}$ of 5.0 and 6.5.

It must be highlighted that significant differences are found $(\mathrm{p}<0.05)$ in the percentages of biodegradation obtained at higher fermentation times. At $8 \%$ inoculum concentration, more than $16 \%$ fat biodegradation was obtained during the same fermentation time (32 hours). It seems that an increase in cell concentration causes cyanic changes in the microorganism, which result in a low metabolic activity, resulting in a reduction of lipase activity. On the other hand, no significant differences were found $(\mathrm{p}>0.05)$ between inoculum concentrations of $12 \%$ and $16 \%$.

The values of fat removal at different $\mathrm{pH}$ concentrations and fermentation times are shown in Table 2. The highest fat removal value (82.88) was obtained at $\mathrm{pH} 5$ using an inoculum concentration of $16 \%$, while the lowest value (47.50) was reached at $\mathrm{pH} 5$ and an inoculum concentration of $8 \%$. It should be highlighted that significant differences $(p<0.05)$ were found for all the fermentation times.

Table 2. Percentage of fat biodegradation using CEE at two $\mathrm{pH}$ values over 32 days.

\begin{tabular}{ccccccc}
\hline \multicolumn{5}{c}{ Fat removal (\%) } \\
\hline \multirow{3}{*}{ Time (hours) } & \multicolumn{4}{c}{$p H 6.5$} \\
\cline { 2 - 7 } & \multicolumn{7}{c}{ Concentration of CEE Y. lipolytica } & Concentration of CEE Y. lipolytica \\
\cline { 2 - 7 } & $8 \%$ & $12 \%$ & $16 \%$ & $8 \%$ & $12 \%$ & $16 \%$ \\
\hline 8 & $47.50^{\mathrm{a}}$ & $48.89^{\mathrm{a}}$ & $50.18^{\mathrm{a}}$ & $49.63^{\mathrm{a}}$ & $49.81^{\mathrm{a}}$ & $47.79^{\mathrm{a}}$ \\
16 & $59.29^{\mathrm{b}}$ & $62.39^{\mathrm{b}}$ & $58.98^{\mathrm{b}}$ & $55.88^{\mathrm{b}}$ & $53.65^{\mathrm{b}}$ & $51.16^{\mathrm{b}}$ \\
24 & $70.00^{\mathrm{c}}$ & $69.60^{\mathrm{c}}$ & $67.23^{\mathrm{c}}$ & $61.07^{\mathrm{c}}$ & $57.66^{\mathrm{c}}$ & $54.93^{\mathrm{c}}$ \\
32 & $80.52^{\mathrm{d}}$ & $81.22^{\mathrm{d}}$ & $82.88^{\mathrm{d}}$ & $66.77^{\mathrm{d}}$ & $60.85^{\mathrm{d}}$ & $59.01^{\mathrm{d}}$ \\
\hline
\end{tabular}

Rows with no common letter showed statistically significant difference (significance leven0.05). 


\section{CONCLUSIONS}

The study showed that fatty effluent from the dairy industry contains high levels of $\mathrm{BOD}_{5}$, COD, total solids and fat. The results show that CEE from strain culture (Yarrowia lipolytica) reduced the levels of $\mathrm{BOD}_{5}$ and $\mathrm{COD}$ until reaching the values of 43.32 and $44.3 \%$, respectively. Likewise, the $Y$. lipolytica ATCC 9773 strain is able to biodegrade the fat content of the effluent to values close to $82.88 \%$. These results may have relevant implications in the industry for the reduction of the contamination of effluents with large amounts of contaminating material, specifically fat.

\section{ACKNOWLEDGMENT}

The authors are especially grateful to the University of Cartagena for all their collaboration during the development of the research.

\section{REFERENCES}

ABASS, O. A.; JAMEEL, A. T.; MUYUBI, S. A.; ABDUL KARIM, M. I.; ALAM, M. Z. Removal of Oil and Grease as Emerging Pollutants of Concern (EPC) in Wastewater Stream. IIUM Engineering Journal, v. 12, n. 4, p. 161-169, 2011. https://doi.org/10.31436/iiumej.v12i4.218

Aloulou, A.; RODRÍGUEZ, J. A.; PUCCINELli, D.; MOUZ, N.; LECLAIRE, J.; LEBLOND, Y.; CARRIÈRE, F. Purification and biochemical characterization of the LIP2 lipase from Yarrowia lipolytica. Biochimica et Biophysica Acta (BBA) Molecular and Cell Biology of Lipids, v. 1771, n. 2, p. 228-237, 2007. https://doi.org/10.1016/j.bbalip.2006.12.006

APHA; AWWA; WEF. Standard Methods for the examination of water and wastewater. 22nd ed. Washington, 2012. 1496 p.

BECERRA-GUTIÉRREZ, L. K.; HORNA-ACEVEDO, M. V.; BARRIONUEVO-ALBÚJAR, K. I. Influence of natives microorganisms in treatment of slaughterhouses waste water. Revista del Cuerpo Médico del Hospital Nacional Almanzor Aguinada Asenjo, v. 8. n. 1. p. 15-18, 2015. https://doi.org/10.35434/rcmhnaaa.2015.81.231

BRIGIDA, A. I. S.; AMARAL, P. F. F.; COELHO, M. A. Z.; GONÇALVES, L. R. B. Lipase from Yarrowia lipolytica: Production, characterization and application as an industrial biocatalyst. Journal of Molecular Catalysis Enzymatic, v. 101, p. 148-158, 2014. https://doi.org/10.1016/j.molcatb.2013.11.016

COSA, S.; OKOH, A. Bioflocculant production by a consortium of two bacterial species and its potential application in industrial wastewater and river water treatment Polish Journal of Environmental Studies, v. 23, n. 3, p. 689-696, 2014.

DAS, S.; SANTRA, S. C. Simultaneous biomass production and mixed-origin wastewater treatment by five environmental isolates of Cyanobacteria. Biologija, v. 56, n. 1-4, p. 913, 2010. https://dx.doi.org/10.2478/v10054-010-0010-7

DARVISHI, F.; FATHI, Z.; ARIANA, M.; MORADI, M. Yarrowia lipolytica as a work horse for biofuel production. Biochemical Engineering Journal, v. 127. n. 15, p. 87-96, 2017. https://doi.org/10.1016/j.bej.2017.08.013 
DEIVE, F. J.; SANROMÁN, M. A.; LONGO, M. A. A comprehensive study of lipase production by Yarrowia lipolytica CECT 1240 (ATCC 18942): from shake flask to continuous bioreactor. Journal of Chemical Technology and Biotechnology, v. 85, n. 2, p. 258- 266, 2010. https://doi.org/10.1002/jctb.2301

FACCHIN, S.; DINIZ, P.; SIQUEIRA, F. et al. Biodiversity and secretion of enzymes with potential utility in wastewater treatment. Open Journal of Ecology, v. 3, n. 1, p. 34-47. 2013. http://dx.doi.org/10.4236/oje.2013.31005

FICKERS, P.; FUDALEJ, F.; LE DALL, M. T.; CASAREGOLA, S.; GAILLARDIN, C.; THONART, P.; NICAUD, J. M. Identification and characterisation of LIP7 and LIP8 genes encoding two extracellular triacylglycerol lipases in the yeast Yarrowia lipolytica. Fungal Genetics and Biology, v. 42, n. 3, p. 264-274, 2005. https://doi.org/10.1016/j.fgb.2004.12.003

GAIKWAD, G. L.; WATE, S. R.; RAMTEKE, D. S.; ROYCHOUDHURY, K. Development of microbial consortia for the effective treatment of complex wastewater. Journal of. Bioremediation \& Biodegradation, v. 5, p. 4, 2014. https://dx.doi.org/10.4172/21556199.1000227

GONZÁLEZ, D.; AMAÍZ, L.; MEDINA, L.; VARGAS, R.; IZZEDDIN, N.; VALBUENA, O. Biodegradación de residuo graso industrial empleando bacterias endógenas. Revista Latinoamericana de Biotecnologia Ambiental y Algal, v. 3, n. 2, p. 105-118, 2012.

GUILLEN-JIMENEZ, E.; ALVAREZ-MATEOS, P.; ROMERO-GUZMAN, F.; PEREDAMARTIN, J. Bio- mineralization of organic matter in dairy wastewater, as Affected by $\mathrm{pH}$. The evolution of ammonium and phosphates. Water Research, v. 34, p. 1215-1224, 2000. https://doi.org/10.1016/S0043-1354(99)00242-0

KUMARI, A.; RAZI, A.; NEGI, S.; KHARE, S. Biodegradation of waste grease by Penicillium chrysogenum for production of fatty acid. Bioresource Technology, v. 226, p. 31-38, 2017. https://doi.org/10.1016/j.biortech.2016.12.006

KUSHWAHA, J. P.; SRIVASTAVA, V. C.; MALL, I. D. An Overview of Various Technologies for the Treatment of Dairy Wastewaters. Critical Reviews in Food Science

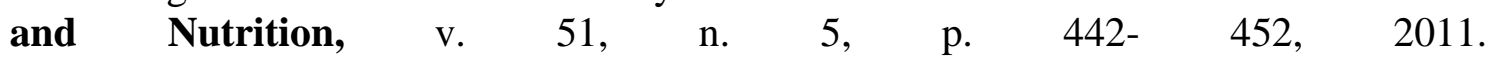
https://doi.org/10.1080/10408391003663879

LIU, H.; JI, X.; HUANG, H. Biotechnological applications of Yarrowia lipolytica: past. present and future. Biotechnology Advances, v. 33, n. 8, p. 1522-1546, $2015 \mathrm{a}$. https://doi.org/10.1016/j.biotechadv.2015.07.010

LIU, Y.; KANG, X.; LI, X. L.; YUAN, Y. Performance of aerobic granular sludge in a sequencing batch bioreactor for slaughterhouse wastewater treatment. Bioresource technology, v. 190, p. 487-491, 2015b. https://doi.org/10.1016/j.biortech.2015.03.008

LOPES, M.; GOMES, A.; SILVA, C.; BELO, I. Microbial lipids and added value metabolites production by Yarrowia lipolytica from pork lard. Journal of Biotechnology, v. 265, p. 76-85, 2018. https://doi.org/10.1016/j.jbiotec.2017.11.007

ORHON, D.; GÖRGÜN, E.; GERMIRLI, F.; ARTAN, N. Biological treatability of dairy wastewaters Water Research, v. 27, p. 625-633, 1993. https://doi.org/10.1016/00431354(93)90172-E 
PILUSA, T. J.; MUZENDA, E.; SHUKLA, M. Thermo-chemical extraction of fuel oil from waste lubricating grease. Waste Management, v. 33, p. 1509-1515, 2013. https://doi.org/10.1016/j.wasman.2013.02.014

PORWAL, H. J.; MANE, A. V.; VELHAL, S. Biodegradation of Dairy Effluent by Using Microbial Isolates Obtained from activated sludge. Water Resources and Industry, v. 9, p. 1-15, 2015. https://doi.org/10.1016/j.wri.2014.11.002

STEFAŃSKA, B.; KOMISAREK, J.; STANISŁAWSKI, D.; GĄSIOREK, M.; NOWAK, W. The effect of Yarrowia lipolytica culture on growth performance. ruminal fermentation and blood parameters of dairy calves. Animal Feed Science and Technology, v. 243, p. 72-79, 2018. https://doi.org/10.1016/j.anifeedsci.2018.06.013

TARON-DUNOYER, A. A.; GUZMAN-CARRILLO, L. E.; BARROS-PORTNOY, I. Evaluación de la Cassia fistula como coagulante natural en el tratamiento primario de aguas residuales. Orinoquia, v. 21, n. 1, p. 73-78, 2017. http://dx.doi.org/10.22579/20112629.396

WU, L.; WAN, J. B. Investigation on the capability of disposing the grease wastewater with Immobilized Yarrowia lipolytica. Chinese Journal of Environmental Engineering, v. 4, n. 2, p. 482-486, 2008.

WU, L.; GE, G.; WAN, J. Biodegradation of oil wastewater by free and immobilized Yarrowia lipolytica W29. Journal of Environmental Sciences, v. 21, n. 2, p. 237-242, 2009. https://doi.org/10.1016/S1001-0742(08)62257-3 